ISSN 0103-8478

\title{
Reaction of common bean progenies to white mold derived from recurrent selection
}

\author{
Reação de progênies de feijão ao mofo branco derivadas de seleção recorrente
}

\author{
Danuza Araújo de Souza ${ }^{\mathrm{I}^{*}}$ Fernanda Aparecida Castro Pereira $^{\mathrm{II}}$ \\ Juliana Andrade Dias ${ }^{\mathrm{I}}$ Monik Evelin Leite ${ }^{\mathrm{I}}$ João Bosco dos Santos ${ }^{\mathrm{I}}$
}

\section{ABSTRACT}

This study was realized with the objective of verifying the resistance to white mold of common bean progenies derived from recurrent selection for resistance to angular leaf spot. The plant material used was obtained from a program of recurrent selection, which was started by crossing seven lines with carioca grain type with ten sources of resistance to angular leaf spot according to the partial diallel scheme. To evaluate the resistance to white mold, it was verified the reaction of 17 parents plus 35 selected progenies, to oxalic acid. Huge heterogeneity among the parents was observed, showing that some of them have resistance alleles to white mold, and thus, there is a possibility of recombine these alleles through the recurrent selection and obtaining progenies with high levels of resistance. Even in initial cycles, some progenies exhibited resistance to white mold similar to the one of cultivar ' $G-122$ ', which presents good level of resistance to this disease. This leads to infer that the original population already had some level of physiological resistance for the reaction to absorption of oxalic acid, and also for resistance to angular leaf spot. Thus, among the selected progenies for resistance to angular leaf spot, grain type and high yield, at least four progenies have resistance to white mold similar to the source of resistance ' $G-122$ '.

Key words: Phaseolus vulgaris, oxalic acid, physiological resistance.

\section{RESUMO}

Este estudo foi realizado com o objetivo de verificar a resistência ao mofo branco de progênies de feijão, provenientes de seleção recorrente para resistência à mancha angular. O material vegetal utilizado foi obtido de um programa de seleção recorrente, iniciado com o intercruzamento entre sete linhagens com grãos tipo carioca e dez fontes de resistência à mancha angular no esquema dialelo parcial. Para avaliação da resistência ao mofo branco, foi verificada a reação desses 17 genitores mais as 35 progênies obtidas, ao ácido oxálico. Foi observada uma ampla variabilidade nos genitores, indicando que alguns possuem alelos de resistência ao mofo branco e, assim, há possibilidade de associação desses alelos no programa de seleção recorrente e obtenção de progênies com níveis superiores de resistência. As progênies que se apresentaram como mais resistentes foram MAV-1.7, MAV-3.36, MAVI-21 e MAVI-60. Mesmo em ciclos iniciais, algumas progênies apresentaram nota média de reação ao mofo branco semelhante à da cultivar 'G-122', que apresenta bom nível de resistência a essa doença. Isso leva a inferir que a população original utilizada já possuía algum nível de resistência fisiológica para a reação à absorção ao ácido oxálico e também para a resistência à mancha angular. Assim, entre as progênies selecionadas para a resistência à mancha angular, tipo de grão e produtividade, pelo menos quatro apresentam nível de resistência ao mofo branco semelhante à fonte de resistência ' $G$-122'.

Palavras-chave: Phaseolus vulgaris, ácido oxálico, resistência fisiológica.

\section{INTRODUCTION}

In general, the occurrence of diseases contributes to low yield, instability in the production and a high risk of implantation of bean crop. Among the diseases that have limited the obtaining of high yield in common bean crop, white mold (Sclerotinia sclerotiorum) and angular leaf spot (Pseudocercospora griseola) stand out.

For angular leaf spot, the resistance has been attributed to one, two, three or more independent genes, in some cases dominant, in others recessive, some of them with allelic forms, and can be found in several cultivars. However, almost all cultivars

\footnotetext{
'Departamento de Biologia, Universidade Federal de Lavras (UFLA), Campus Universitário, 37200-000, Lavras, MG, Brasil. E-mail: danuzza19@yahoo.com.br.*Autor para correspondência.

IIDepartamento de Genética, Escola Superior de Agricultura “Luiz de Queiroz”, Universidade de São Paulo (USP), Piracicaba, SP, Brasil. 
used in the country are, to a greater or lesser degree, susceptible to angular leaf spot (CAIXETA et al., 2005), also suggesting the existence of horizontal resistance. In such situations, one of the alternatives to accumulate the several resistance alleles is the recurrent selection, a cyclical and dynamic system, which aims to increase gradually the frequency of favorable alleles for a quantitative characteristic, through repeated cycles of selection, evaluation and recombination (RAMALHO et al., 2005). In the case of self-pollinated plants, there are plenty of results that prove their efficiency (WIERSMA et al., 2001; RAMALHO et al., 2005; AMARO et al., 2007; ARANTES et al., 2010).

In relation to the white mold, it is known that there is more damage, especially in winter and in cultivations under irrigation. The white mold affects severely the plant, and the cultivars in use in Brazil do not have adequate resistance level (GONÇALVES \& SANTOS, 2010). A procedure used for identifying resistance sources to this disease is an indirect method, through the reaction to oxalic acid. Tests conducted in greenhouses and in the field showed the most tolerant genotypes to oxalic acid are also the most resistant ones to white mold. The reason for this fact is due to the oxalic acid is the primary factor of pathogenicity of the fungus (KOLKMAN \& KELLY, 2000).

Aggregating in an only plant, resistance to angular leaf spot and to white mold, would be a fact of extreme importance for obtaining a new cultivar, and also for increasing the grain yield. Thus, if resistant progenies to both diseases were found, they would be more promising as new cultivars.

Thus, the aim of this research was to verify the resistance of common bean progenies to white mold, evaluated through the reaction to oxalic acid.

\section{MATERIAL AND METHODS}

The plant material used was the parents and selected progenies through a program of recurrent selection for resistance to angular leaf spot and carioca grain type. The base population was obtained intercrossing in the partial diallel scheme, seven lines with carioca grain type (Carioca MG, CI-140, CI-128, ANPAT 8.12, IAPAR 81, ESAL 693 and Pérola) and ten resistance sources to angular leaf spot (P. griseola) (AN 512561, AND 277, Ouro Negro, Compuesto Negro Chimaltenango, CAL 143, MAR 2, MAR 1, G 5686, MA 4.137 and Jalo), including various grains types. All the procedure used for obtaining the 35 progenies (five progenies selected in seven cycles of recurrent selection) is described in ARANTES et al. (2010).
Besides the parents and progenies, a susceptible check (IPR-Corujinha) and a resistant check ('G-122') to white mold were used. The cultivar 'Corujinha' belongs to the commercial carioca group and it was named this way due to the peculiar appearance of its grains: a lite brown mottle on a lite cream background. It has upright plant, favoring the mechanical harvesting. This cultivar is highly susceptibility to white mold. The cultivar ' $\mathrm{G}$ 122' has determined growth habit (type I), Andean origin, big seeds, red mottle on a cream background. This cultivar has showed field resistance to white mold (SINGH, 1982; STEADMAN et al., 1998), which probably, results from physiological resistance (MIKLAS et al., 2001).

Sixty seeds of each one of the 54 genotypes were sown (35 progenies from the recurrent selection, 17 parents, and susceptible and resistant checks), in polystyrene trays containing commercial substrate Plantmax $^{\circledR}$. It was sown a seed per cell of the tray. After the emergence of the second trifoliate leaf, around 20 days after the sowing, the 30 most uniform plants were selected.

Due to the limitation of space in the laboratory, five experiments were carried out, using susceptible cultivar 'Corujinha' as common check in each experiment. In four of these experiments, 12 genotypes were evaluated each time, and in the fifth one, the other 10 genotypes were evaluated (which totalize 58 treatments referring to 54 genotypes plus the common check 'Corujinha' in the other four experiments). Each experiment was set up using the completed randomized design with three repetitions, being each plot represented by 10 plants.

Plants of 20 to 21 days old with trifoliate leaves emitted were used. They were cut on stem base in the afternoon, and the inferior part of the stem $(2 \mathrm{~cm})$ was immersed in solution of oxalic acid $20 \mathrm{mM}$, kept in a plastic container from 15 to 20 hours during the night in protected environment. The solution had $\mathrm{pH}$ adjusted to 4 with sodium hydroxide $(\mathrm{NaOH})$. The control (treatment without oxalic acid) consisted in container with distilled water ( $\mathrm{pH} 4)$, in which the check was placed immersed.

The reaction of each plant was determined through the scores proposed by KOLKMAN \& KELLY (2000): 1. Absence of wilt leaves; 2. A trifoliate leaf or both wilt unifoliate; 3. Two wilt leaves; 4. More than two wilt leaves; 5 . Wilt leaves and petioles and 6. Plant completely wilt. A score was given by plant. The wilt symptoms cover from the roll of the tip of the leaf until the total turgidity loss of the whole leaf. 
Initially, the mean was obtained by plot. The data of mean score per plot were submitted to the variance analysis. The group analysis of the five experiments was carried out through PROC GLM procedure of SAS software (STATISTICAL ANALYSIS SYSTEM INSTITUTE - SAS INSTITUTE, 2000). Afterwards, the adjusted means of the different genotypes were grouped by the test of SCOTT \& KNOTT (1974), at 5\% of probability. The heritabilities and the confidence intervals were estimated according to the expression of KNAPP et al. (1985). The studies of heritability have been used in populations whose individuals constitute a random sample. When applied to a set of pre-selected genetic materials, it is common to use the expression genotypic determination coefficient, which is similar to heritability, and expresses the amount of phenotypic variation observed, which is due to genetic causes, such as in the particular progenies group evaluated. This estimate will be referred to as heritability $\left(\mathrm{h}^{2}\right)$. Moreover, for each experiment, statistics experimental coefficient of variation (CVe) and selective accuracy $\left(r_{g g}\right)$ were estimated (RESENDE \& DUARTE, 2007).

\section{RESULTS AND DISCUSSION}

Significant genotypic differences $(\mathrm{P}<0,01)$ were found among the genotypes evaluated, as were observed by some authors that used the same methodology for common bean (GONÇALVES \& SANTOS, 2010) (Table 1). The difference among the progenies shows the existence of genetic variability, which is promising for identifying those with resistance to both diseases. It was not observed wilt symptoms in control plants like in KOLKMAN \& KELLY (2000). This fact indicates that the wilt of the plants was due to the oxalic acid. The experiment was carried out with high experimental accuracy, as it can be seen by CV $(12,43 \%)$ and $r_{g g}(95,38 \%)$.

The main function of heritability is its predictive role, which expresses the reliability of the phenotypic value as estimator of the genotypic value, in such a way that the higher the heritability, the more genetic gain per selection (RAMALHO et al., 1993). Thus, the progenies and parents evaluated in this experiment show a wide variability of reaction to oxalic acid $\left(h^{2}=90,98 \%\right)$, being an indicator of having a big chance of success if the selection is realized.

Among the parents used (Table 2), six of them were grouped in the first group with mean inferior to 1,53 (Group A). Of these, AND 277 presented the lowest mean $(0,83)$. This is an Andean cultivar having resistance alleles to anthracnose and to the angular
Table 1 - Summary of the grouped analysis of variance for reaction of common bean genotypes to white mold through the method of oxalic acid.

\begin{tabular}{lll}
\hline FV & GL & QM \\
\hline Experiments & 4 & $0,79^{* *}$ \\
Genotypes & 53 & $1,33^{* *}$ \\
Among progenies & 34 & $1,30^{* *}$ \\
Among parents & 17 & $1,79 * *$ \\
Progenies vs parents & 1 & $2,05^{* *}$ \\
Regular treatment vs common treatment & 1 & $4,83^{* *}$ \\
Error & 116 & 0,12 \\
Total & 173 & \\
CV(\%) & \\
Mean & & 12,43 \\
$\mathrm{~h}^{2}(\%)^{2}$ & & 2,56 \\
$\mathrm{~h}^{2} \mathrm{UL}$ & & 90,98 \\
$\mathrm{~h}^{2}{ }_{\mathrm{LL}}$ & & 85,36 \\
$r_{g g}{ }^{2}$ & & 94,21 \\
\end{tabular}

**significant, at $1 \%$ of probability, by $\mathrm{F}$ test; ${ }^{1}$ Coefficient of variation; ${ }^{2}$ Heritability estimates with upper $\left(\mathrm{h}^{2} \mathrm{UL}\right)$ and lower $\left(\mathrm{h}_{\mathrm{LL}}^{2}\right)$ limits and superior; ${ }^{3}$ selective accuracy.

leaf spot (ALZATE-MARIN et al., 2003; CAIXETA et al., 2005).This cultivar still has great chances of also having resistance alleles to white mold according

Table 2 - Mean of the score reaction to white mold through the reaction to oxalic acid of the 17 parents used in the beginning of the program of recurrent selection for resistance to angular leaf spot and the checks.

\begin{tabular}{lc}
\hline Parents & Mean* \\
\hline And 277 & $0,83 \mathrm{a}$ \\
G122** & $1,10 \mathrm{a}$ \\
Carioca-mg & $1,10 \mathrm{a}$ \\
Cal 143 & $1,20 \mathrm{a}$ \\
Ma 4.137 & $1,27 \mathrm{a}$ \\
Ci 128 & $1,37 \mathrm{a}$ \\
Comp.negro & $1,53 \mathrm{a}$ \\
Anpat 8.12 & $1,67 \mathrm{~b}$ \\
Mar/01 & $1,87 \mathrm{~b}$ \\
Jalo & $1,87 \mathrm{~b}$ \\
Mar/02 & $2,27 \mathrm{~b}$ \\
Pérola & $2,50 \mathrm{c}$ \\
Iapar 81 & $2,60 \mathrm{c}$ \\
G5686 & $2,67 \mathrm{c}$ \\
Ouro negro & $2,90 \mathrm{~d}$ \\
CI 140 & $3,03 \mathrm{~d}$ \\
Corujinha** & $3,10 \mathrm{~d}$ \\
Esal 693 & $3,67 \mathrm{e}$ \\
\hline
\end{tabular}

*The means followed by the same letter belong to the same group according to the test of Scott-Knott, at $5 \%$ of probability.

** Resistant check: G-122, susceptible check: Corujinha 
to the mean score obtained, of light wilt symptom that characterizes disease resistance.

The significant difference $(\mathrm{P}<0,01)$ among the parents shows that some of them have resistance alleles to white mold (Table 1). Thus, there is a possibility of associating these alleles with the higher levels of resistance of angular leaf spot, grain yield, and the carioca grain type of the selected progenies derived from the recurrent selection.

The progenies were separated in seven different groups according to the data of table 3 . The progenies that showed higher resistance to wilt, being characterized as the most resistant ones were: MAV1.7 and MAV-3.36, which belong to the fifth cycle of selection and the progenies MAVI-21 and MAVI-60, to the sixth cycle. It must be mentioned that even in initial cycles, some progenies showed average score of reaction to white mold similar to that of cultivar ' $\mathrm{G}$ 122', which was used as check, and that has a good level of resistance to $\boldsymbol{S}$. sclerotiorum. ARANTES et al. (2010) did the same observation in relation to the scores of severity to angular leaf spot for the same progenies used in this work. This leads to inferring that the original population already had some level of physiological resistance to the mechanism of reaction for absorption to oxalic acid, once the average score $(1,98)$ of reaction to oxalic acid of parents used in the beginning of the program of recurrent selection for resistance to angular leaf spot was low. The behavior of cultivar ' $\mathrm{G}-122$ ' reported in this work is compatible with those of other studies (KOLKMAN \& KELLY, 2000; ANTÔNIO et al., 2008; GONÇALVES \& SANTOS, 2010;).

In general, the variation and the levels of resistance of the progenies were similar to those of the parents (Tables 2 and 3). The gain with the selection for resistance to angular leaf spot probably resulted in gain for resistance to white mold, so the reaction to oxalic acid is due to mechanisms that are common for resistance to both diseases (CESSNA et al., 2000). Another favorable aspect is the lack of association of resistance with the type of grain, which make it possible to get resistant cultivars with the desired grain type.

Table 3 - Mean of the scores of reaction to white mold through the reaction to oxalic acid, of 35 progenies of common bean from seven cycles of recurrent selection.

\begin{tabular}{|c|c|c|c|c|c|}
\hline Cycle & Progenies & Mean & Cycle & Progenies & Mean \\
\hline \multirow{6}{*}{ I } & MA I - 18.13 & $2,00 \mathrm{~b}$ & \multirow{6}{*}{$\mathrm{V}$} & MAV - 1.7 & $0,82 \mathrm{a}$ \\
\hline & MA I -8.9 & $2,30 \mathrm{~b}$ & & MAV - 3.36 & $1,20 \mathrm{a}$ \\
\hline & MA I - 6.10 & $3,07 d$ & & MAV - 14.206 & $2,53 c$ \\
\hline & MA I - 2.10 & $3,23 d$ & & MAV - 5.60 & 2,90d \\
\hline & MA I - 2.5 & 3,33d & & MAV - 7.85 & $3,00 \mathrm{~d}$ \\
\hline & Mean of C-I & 2,79 & & Mean of C-V & 2,09 \\
\hline \multirow{6}{*}{ II } & MA II - 22 & $1,87 b$ & \multirow{6}{*}{ VI } & MAVI - 21 & $0,97 a$ \\
\hline & MAII - 10 & $2,20 \mathrm{~b}$ & & MAVI - 24 & $1,87 b$ \\
\hline & MAII - 16 & $2,67 c$ & & MAVI - 39 & $1,60 \mathrm{~b}$ \\
\hline & MAII - 2 & $2,97 d$ & & MAVI - 60 & $1,00 \mathrm{a}$ \\
\hline & MAII - 8 & 3,23d & & MAVI - 20 & 3,03d \\
\hline & Mean of C-II & 2,59 & & Mean of C-VI & 1,69 \\
\hline \multirow{6}{*}{ III } & MAIII - 17.179 & $2,20 \mathrm{~b}$ & \multirow{6}{*}{ VII } & MAVII - 34 & $3,07 d$ \\
\hline & MAIII - 17.185 & $3,00 \mathrm{~d}$ & & MAVII - 92 & $3,17 d$ \\
\hline & MAIII - 9.91 & $3,40 \mathrm{~d}$ & & MAVII - 129 & $3,87 \mathrm{e}$ \\
\hline & MAIII - 16.159 & $3,77 \mathrm{e}$ & & MAVII - 127 & $4,10 \mathrm{f}$ \\
\hline & MAIII - 16.155 & $4,37 f$ & & MAVII - 244 & $4,10 f$ \\
\hline & Mean of C-III & 3,35 & & Mean of C-VII & 3,66 \\
\hline \multirow{6}{*}{ IV } & MAIV - 15.203 & $2,57 c$ & & & \\
\hline & MAIV - 8.102 & $3,00 \mathrm{~d}$ & & & \\
\hline & MAIV - 18.524 & $3,20 \mathrm{~d}$ & & & \\
\hline & MAIV - 15.204 & $3,37 d$ & & & \\
\hline & MAIV - 18.259 & $4,3 \mathrm{f}$ & & & \\
\hline & Mean of C-IV & 3,29 & & & \\
\hline
\end{tabular}

*The means followed by the same letter belong to the same group according to the test of Scott-Knott, at 5\% of probability.

** Resistant check: G-122, susceptible check: Corujinha 
It is important to point out the identification of progenies, which besides the superiority for angular leaf spot, architecture and grain type, they also stand out for resistance to white mold (MAV-1.7, MAV-3.36, MAVI-21 and MAVI-60).

\section{CONCLUSION}

Four selected progenies for resistance to angular leaf spot also show partial resistance to white mold.

\section{ACKNOWLEDGEMENTS}

To CNPq (National Research Council) for the financial support to the first author with a master's fellowship.

\section{REFERENCES}

ALZATE-MARIN, A.L. et al. Allelism studies for anthracnose resistance genes of common bean cultivar And 277. Annual Report of the Bean Improvement Cooperative, Fort Collins, v.46, p.173174, 2003. Available from: <http://bic.css.msu.edu/_pdf/Reports/ BIC_2003_volume_46.pdf >. Accessed: Feb. 01, 2012.

ANTÔNIO, R.P. et al. Genetic control of the resistance of common beans to white mold using the reaction to oxalic acid. Genetics and Molecular Research, Ribeirão Preto, v.7, n.3, p.733-740, 2008. Available from: <http://www.funpecrp.com.br/ gmr/year2008/vol7-3/pdf/gmr466_abstract.pdf>. Accessed: Jan. 10, 2012. doi:10.4238/vol7-3gmr466.

AMARO, G.B. et al. Phenotypic recurrent selection in the common bean (Phaseolus vulgaris L.) with carioca-type grains for resistance to the fungi Phaeoisariopsis griseola. Genetics and Molecular Biology, Ribeirão Preto, v.30, n.3, p.584-588, 2007. Available from: <http://www.scielo.br/scielo.php?script=sci_ arttext\&pid=S1415-47572007000400014\&lng=en\&nrm=is o\&tlng=en>. Accessed: Jan. 10, 2012. doi: 10.1590/S141547572007000400014 .

ARANTES, L. de O. et al. Eight cycles of recurrent selection for resistance to angular leaf spot in common bean. Crop Breeding and Applied Biotechnology, Londrina, v.10, n.3, p.232-237, 2010. Available from: <http://www.scielo.br/pdf/cbab/v10n3/ a08v10n3.pdf>. Accessed: Jan. 10, 2012. doi: 10.1590/S198470332010000300008 .

CAIXETA, E.T. et al. Allelic relationships for genes that confer resistance to angular leaf spot in common bean. Euphytica, Wageningen, v.145, n.3, p.237-245, 2005. Available from: <http:// www.springerlink.com/content/f7m1282825365w62/fulltext.pdf>. Accessed: Jan. 10, 2012. doi: 10.1007/s10681-005-1258-3.

CESSNA, S.G. et al. Oxalic acid, a pathogenicity factor for Sclerotinia sclerotiorum, suppresses the oxidative burst of the host plant. Plant Cell, Rockville, v.12, n.11, p.2191-2199, 2000. Available from: <http://www.ncbi.nlm.nih.gov/pmc/ articles/PMC150167/>. Accessed: Jan. 10, 2012. doi: 10.1105/ tpc.12.11.2191.

GONÇALVES, P.R.C.; SANTOS, J.B. dos. Physiological resistance of common bean cultivars and lines to white mold based on oxalic acid reaction. Annual Report of Bean Improvement Cooperative, Fort Collins, v.53, p.236-237, 2010. Available from: <http:// www.css.msu.edu/bic/PDF/Reports/BIC_2010_Volume_53.pdf>. Accessed: Feb. 01, 2012.

INSTITUTO AGRONÔMICO DO PARANÁ. Principais características das cultivares de feijão com sementes disponíveis no mercado. Available from: $<$ http://www.iapar.br/modules/ conteudo/conteudo.php?conteudo=1363>. Accessed: Jan. 10, 2012.

KNAPP, S.J. et al. Exact confidence intervals for heritability on a progeny mean basis. Crop Science, Madison, v.25, n.1, p.192194, 1985. Available from: <https://www.soils.org/publications/ cs/abstracts/25/1/CS0250010192>. Accessed: Feb. 11, 2012.

KOLKMAN, J.M.; KELLY, J.D. An indirect test using oxalate to determine physiological resistance to white mold in common bean. Crop Science, Madison, v.40, n.1, p.281-285, 2000. Available from: <https://www.soils.org/publications/cs/articles/40/1/281>. Accessed: Feb. 11, 2012. doi: 10.2135/cropsci2000.401281x.

MIKLAS, P.N. et al. QTL conditioning physiological resistance and avoidance to white mold in dry bean. Crop Science, Madison, v.41, n.2, p.309-315, 2001. Available from: <https://www.crops. org/publications/cs/articles/41/2/309>. Accessed: Feb. 11, 2012. doi: $10.2135 /$ cropsci2001.412309x.

RAMALHO, M.A.P. et al. Genética quantitativa em plantas autógamas: aplicações ao melhoramento do feijoeiro. Goiânia: UFG, 1993. 271p.

RAMALHO, M.A.P. et al. Genetic progress after four cycles of recurrent selection for yield and grain traits in common bean. Euphytica, Wageningen, v.144, n.1/2, p.23-29, 2005. Available from: <http://www.springerlink.com/content/r6852766k1j82078/fulltext. pdf>. Accessed: Jan. 10, 2012. doi: 10.1007/s10681-005-5694-X.

RESENDE, M.D.V.; DUARTE, J.B. Precisão e controle de qualidade em experimentos de avaliação de cultivares. Pesquisa Agropecuária Tropical, Goiânia, v.37, n.3, p.182-194, 2007. Available from: <http://www.revistas.ufg.br/index.php/pat/article/ view/1867/1773>. Accessed: Jan. 10, 2012.

SCOTT, A.J.; KNOTT, M. A cluster analysis method for grouping means in the analysis of variance. Biometrics, Washington, v.30, p.507-512, 1974. Available from: <http://www.jstor.org/di scover $/ 10.2307 / 2529204$ ? uid=2129\&uid $=2 \&$ uid=70\&uid=4\&s id=21101173281223>. Accessed: Jan. 10, 2012.

SINGH, S.P. A key for identification of different growth habits of Phaseolus vulgaris L. Annual Reports Bean Improvement Cooperative, Fort Collins, v.25, p.92-95, 1982.

STATISTICAL ANALYSIS SYSTEM INSTITUTE. SAS/STATS user's guide. Version 8. Cary, 2000. 842p.

STEADMAN, J.R. et al. Bean white mold nursery. Annual Reports Bean Improvement Cooperative, Fort Collins, v.41, p.173-174, 1998. Available from: <http://naldc.nal.usda.gov/ download/IND50000046/PDF>. Accessed: Mar. 22, 2012.

WIERSMA, J.J. et al. Recurrent selection for kernel weight in spring wheat. Crop Science, Madison, v.41, n.4, p.999-1005, 2001. Available from: <https://www.soils.org/publications/cs/ articles/41/4/999>. Accessed: Feb. 05, 2012. doi: 10.2135/ cropsci2001.414999x. 